Article

\title{
New 2-Methoxy Acetylenic Acids and Pyrazole Alkaloids from the Marine Sponge Cinachyrella sp.
}

\author{
Amin Mokhlesi ${ }^{1,2}$, Rudolf Hartmann ${ }^{3}$, Tibor Kurtán ${ }^{4}$, Horst Weber ${ }^{5}$, Wenhan Lin ${ }^{6}$, \\ Chaidir Chaidir ${ }^{7}$, Werner E. G. Müller ${ }^{8}$, Georgios Daletos ${ }^{1, *}$ and Peter Proksch ${ }^{1, *}$ \\ 1 Institute of Pharmaceutical Biology and Biotechnology, Heinrich Heine University, Universitätsstraße 1, \\ 40225 Düsseldorf, Germany; amin.mokhlesi@uni-duesseldorf.de \\ 2 Department of Marine Biology, Faculty of Marine Sciences, Tarbiat Modares University, 46414-356 Noor, Iran \\ 3 Institute of Complex Systems: Strukturbiochemie, Forschungszentrum Jülich GmbH, ICS-6, 52425 Jülich, \\ Germany; r.hartmann@fz-juelich.de \\ 4 Department of Organic Chemistry, University of Debrecen, 4002 Debrecen, Hungary; \\ kurtan.tibor@science.unideb.hu \\ 5 Institute of Pharmaceutical and Medicinal Chemistry, Heinrich Heine University, Universitätsstraße 1, \\ 40225 Düsseldorf, Germany; Horst.Weber@uni-duesseldorf.de \\ 6 State Key Laboratory of Natural and Biomimetic Drugs, Peking University, Health Science Center, \\ 100191 Beijing, China; whlin@bjmu.edu.cn \\ 7 Center for Pharmaceutical and Medical Technology, Agency for the Assessment and Application Technology, \\ 10340 Jakarta, Indonesia; chaidir@bppt.go.id \\ 8 Institute of Physiological Chemistry, University Medical Center of the Johannes Gutenberg University \\ Mainz, 55128 Mainz, Germany; wmueller@uni-mainz.de \\ * Correspondence: georgios.daletos@uni-duesseldorf.de (G.D.); proksch@uni-duesseldorf.de (P.P.); \\ Tel.: +49-211-81-14173 (G.D.); +49-211-81-14163 (P.P.)
}

Received: 5 August 2017; Accepted: 6 November 2017; Published: 11 November 2017

\begin{abstract}
Three new 2-methoxy acetylenic acids (1-3) and a known derivative (4), in addition to three new natural pyrazole alkaloids (5-7) were isolated from an Indonesian marine sponge of the genus Cinachyrella. Compounds $\mathbf{5}$ and $\mathbf{6}$ have previously been reported as synthetic compounds. The structures of the new compounds were established on the basis of one- and two-dimensional NMR spectroscopy as well as by mass spectrometric data. The absolute configuration of the new acetylenic acid derivatives (1-3) was established by ECD spectroscopy. All isolated compounds were evaluated for their cytotoxicity against L5178Y mouse lymphoma cells. Compounds 1-4 exhibited strong activity with an $\mathrm{IC}_{50}$ value of $0.3 \mu \mathrm{M}$. A plausible biosynthetic pathway for the pyrazole metabolites $5-7$ is proposed.
\end{abstract}

Keywords: natural products; marine sponge; Cinachyrella sp.; 2-methoxy acetylenic acid; pyrazole alkaloid

\section{Introduction}

Marine sponges (phylum Porifera) are sessile filter feeder animals with the ability to produce bioactive secondary metabolites as an efficient defence mechanism against predators, fouling organisms or pathogenic microorganisms [1]. Several of these metabolites possess pronounced biological activities in disease relevant screens and have proven to be a valuable source of novel lead compounds in drug discovery. Prominent examples of drug leads based on marine natural products include halichondrin B (macrocyclic polyether; lead structure of anticancer drug Halaven ${ }^{\circledR}$ ), dictyodendrins (pyrrolocarbazole derivatives; lead structures of a preclinical telomerase inhibitor), and sarcodictyin (diterpene; lead structure of a preclinical tubulin inhibitor) from the sponges Halichondria okadai, Dictyodendrilla verongiformis, and Sarcodictyon roseum, respectively [2]. 
Sponges of the genus Cinachyrella sp. are mostly known for the production of steroids [3] and fatty acid metabolites, such as the 2-methoxy acetylenic acid derivative cinachylenic acid A from C. australiensis [4], or long-chain isoprenoid fatty acids from C. schulzei [5,6]. In addition, sterols have been used in chemotaxonomic studies of C. cavernosa [7]. Notably, enigmazole A, an unprecedented phosphate-containing macrolide from the Papua New Guinea marine sponge C. enigmatica, has been reported to exhibit pronounced cytotoxicity against the NCI60 human tumour cell line and to interfere with c-Kit receptor signaling, a transmembrane glycoprotein with tyrosine kinase activity, which is involved in the growth and development of various cancers [8].

As part of our ongoing search on bioactive secondary metabolites from marine sponges, we investigated a specimen of Cinachyrella sp. collected at Ambon Island in Indonesia. The MeOH extract exhibited significant activity against the murine lymphoma L5178Y cell line at a concentration of $10 \mu \mathrm{g} / \mathrm{mL}$. Chromatographic separation of the extract afforded three new (1-3) acetylenic acid derivatives and one known (4) congener, in addition to three pyrazole alkaloids (5-7) (Figure 1). Herein, we report the structure elucidation and cytotoxic activity of the isolated compounds and provide a rationale for the biosynthesis of the pyrazole derivatives.

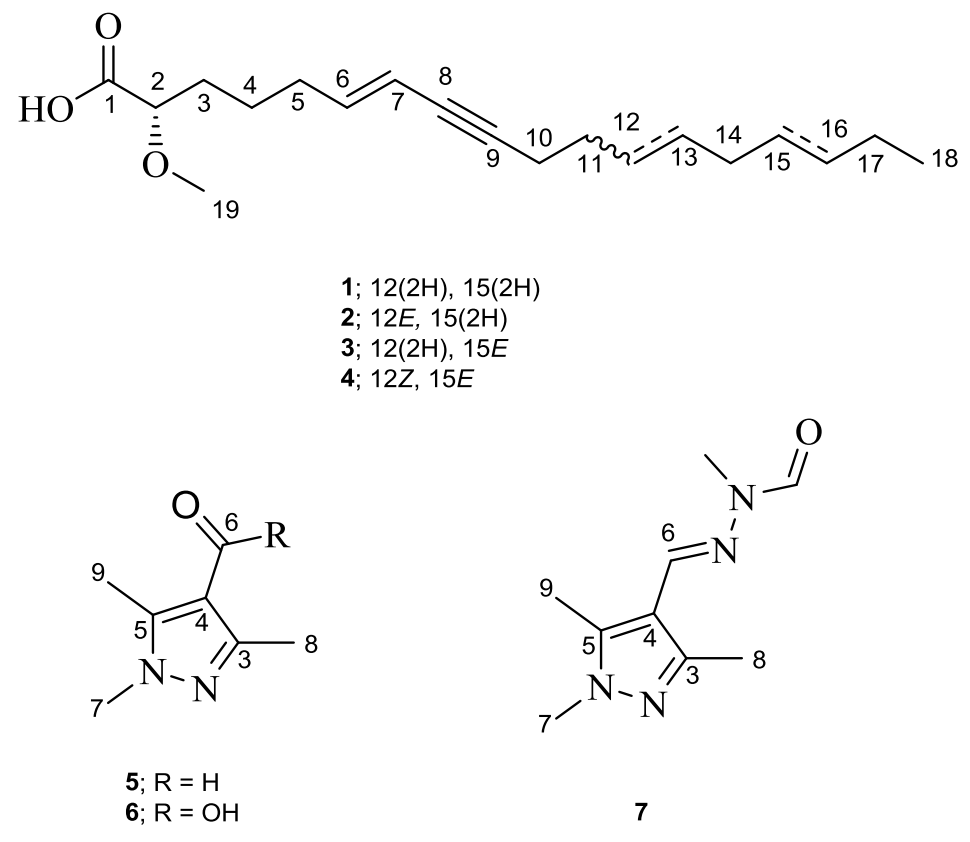

Figure 1. Structures of 1-7.

\section{Results}

\subsection{Cinachylenic Acid B (1)}

Cinachylenic acid B (1) was obtained as yellow oil. The molecular formula was determined as $\mathrm{C}_{19} \mathrm{H}_{32} \mathrm{O}_{3}$ on the basis of the pseudomolecular ion peak at $m / z 309.2420[\mathrm{M}+\mathrm{H}]^{+}$in the high-resolution electrospray ionization mass spectrometry (HRESIMS) spectrum indicating four degrees of unsaturation. In the ${ }^{1} \mathrm{H}$ NMR spectrum, the fatty acid nature of $\mathbf{1}$ was apparent from the presence of a cluster of eleven methylene groups $\left(\delta_{\mathrm{H}} 1.30-2.26\right)$ as well as a terminal methyl group at $\delta_{\mathrm{H}} 0.90\left(\mathrm{H}_{3}-18\right)$. Moreover, the ${ }^{1} \mathrm{H}$ NMR spectrum revealed signals at $\delta_{\mathrm{H}} 5.46(\mathrm{H}-7)$ and $5.95(\mathrm{H}-6)$ corresponding to an E-configurated disubstituted double bond on the basis of the large coupling constant $\left({ }^{3} J=15.8 \mathrm{~Hz}\right)$, as well as a methoxy group and an oxygenated methine proton ( $\left.\mathrm{H}-2\right)$ based on their integration and low field resonances at $\delta_{\mathrm{H}} 3.36$ and 3.76, respectively (Table 1). The COSY spectrum of $\mathbf{1}$ showed two continuous spin systems corresponding to the fragments extending from $\mathrm{H}-2$ to $\mathrm{H}-7$ and from $\mathrm{H}_{2}-10$ to $\mathrm{H}_{3}-18$ (Figure 2). The $\mathrm{HMBC}$ spectrum confirmed the identified substructures 
and established their connection through key ${ }^{3} J$-correlations from $\mathrm{H}-6$ and $\mathrm{H}_{2}-10$ to C-8 $\left(\delta_{\mathrm{c}} 79.9\right)$ and from $\mathrm{H}_{2}-11$ to $\mathrm{C}-9\left(\delta_{\mathrm{C}} 89.2\right)$, denoting the presence of an alkyne group (C-8/9) in the structure of 1 (Figure 2). In addition, the correlation from $\mathrm{H}-2$ and $\mathrm{H}_{2}-3$ to the ester carbonyl at $\delta_{\mathrm{c}} 176.0(\mathrm{C}-1)$, suggested a terminal carboxylic acid group being located at $\mathrm{C}-2$. Likewise, the remaining methoxy group $\left(2-\mathrm{OCH}_{3}\right)$ was assigned at $\mathrm{C}-2$, as confirmed by inspection of the respective HMBC correlation. Thus, the planar structure of $\mathbf{1}$ was established as shown in Figure 1. This assignment was further supported by EIMS, which showed fragmentation ions at $m / z 178$ and 263, presumably originating from cleavage at C-5/6 and C-1/2, respectively (Figure S1-5). Hence, compound 1 was identified as a new natural product and was named cinachylenic acid $\mathrm{B}$.
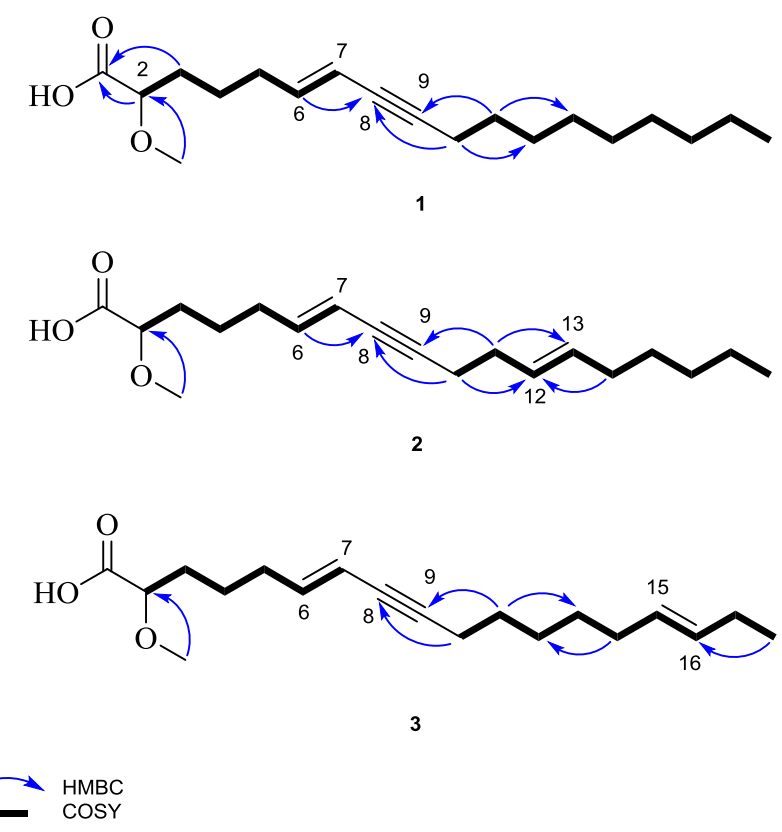

Figure 2. HMBC and COSY correlations of 1-3.

Table 1. ${ }^{1} \mathrm{H}(600 \mathrm{MHz}),{ }^{13} \mathrm{C}(150 \mathrm{MHz}), \mathrm{COSY}$, and HMBC data of cinachylenic acid B (1) in MeOH- $d_{4}$, $\delta$ in ppm.

\begin{tabular}{ccccc}
\hline Position & ${ }^{13} \mathbf{C}, \mathbf{T y p e}^{\mathbf{1}}$ & ${ }^{\mathbf{1}} \mathbf{H}, \mathbf{m}(\boldsymbol{J}$ in $\mathbf{H z})$ & $\mathbf{C O S Y}$ & HMBC \\
\hline 1 & $176.0, \mathrm{C}$ & -3 & -3 & -3 \\
2 & $80.9, \mathrm{CH}$ & $3.76, \mathrm{dd}(7.6,4.6)$ & $3-\mathrm{H}$ & $\mathrm{C}-1 / 3 / 4 / 19$ \\
3 & $32.8, \mathrm{CH}_{2}$ & $1.74, \mathrm{~m} ; 1.68, \mathrm{~m}$ & $2 / 4-\mathrm{H}$ & $\mathrm{C}-1 / 2 / 4 / 5$ \\
4 & $25.3, \mathrm{CH}_{2}$ & $1.50^{2}$ & $3 / 5-\mathrm{H}$ & $\mathrm{C}-2 / 5 / 6$ \\
5 & $33.1, \mathrm{CH}_{2}$ & $2.10, \mathrm{br} \mathrm{qt}(7.2,1.9)$ & $4 / 6-\mathrm{H}$ & $\mathrm{C}-3 / 4 / 6 / 7$ \\
6 & $142.7, \mathrm{CH}$ & $5.95, \mathrm{dt}(15.8,7.1)$ & $5 / 7-\mathrm{H}$ & $\mathrm{C}-5 / 8$ \\
7 & $111.4, \mathrm{CH}$ & $5.46, \mathrm{dt}(15.8,1.9)$ & $6-\mathrm{H}$ & -3 \\
8 & $79.9, \mathrm{C}$ & -3 & -3 & -3 \\
9 & $89.2, \mathrm{C}$ & -3 & -3 & -3 \\
10 & $19.6, \mathrm{CH}_{2}$ & $2.26, \mathrm{br} \mathrm{td}(7.0,2.1)$ & $11-\mathrm{H}$ & $\mathrm{C}-7 / 8 / 9 / 11 / 12$ \\
11 & $29.5, \mathrm{CH}_{2}$ & $1.49^{2} ; 1.40, \mathrm{~m}$ & $10 / 12-\mathrm{H}$ & $\mathrm{C}-9 / 10 / 13$ \\
12 & $29.5, \mathrm{CH}_{2}$ & $1.30^{2}$ & $11 / 13-\mathrm{H}$ & -3 \\
13 & $30.4, \mathrm{CH}_{2}$ & $1.30^{2}$ & $12 / 14-\mathrm{H}$ & -3 \\
14 & $30.4, \mathrm{CH}_{2}$ & $1.30^{2}$ & $13 / 15-\mathrm{H}$ & -3 \\
15 & $30.4, \mathrm{CH}_{2}$ & $1.30^{2}$ & $14 / 16-\mathrm{H}$ & -3 \\
16 & $32.9, \mathrm{CH}_{2}$ & $1.30^{2}$ & $15 / 17-\mathrm{H}$ & -3 \\
17 & $23.5, \mathrm{CH}_{2}$ & $1.33^{2}$ & $16 / 18-\mathrm{H}$ & $\mathrm{C}-16 / 18$ \\
18 & $14.0, \mathrm{CH}_{3}$ & $0.90, \mathrm{t}(7.0)$ & $17-\mathrm{H}$ & $\mathrm{C}-16 / 17$ \\
19 & $57.9, \mathrm{CH}_{3}$ & $3.36, \mathrm{~s}$ & -3 & $\mathrm{C}-2$ \\
\hline
\end{tabular}

${ }^{1}$ Data extracted from HMBC spectra, ${ }^{2}$ Overlapped signals, ${ }^{3}$ None. 


\subsection{Cinachylenic Acid C (2)}

Compound 2 was isolated as yellow oil. The HRESIMS exhibited the pseudomolecular ion peak at $m / z 307.2266[\mathrm{M}+\mathrm{H}]^{+}$, consistent with the molecular formula $\mathrm{C}_{19} \mathrm{H}_{30} \mathrm{O}_{3}$, thus revealing five degrees of unsaturation. The ${ }^{1} \mathrm{H}$ NMR spectrum of $\mathbf{2}$ was similar to that of $\mathbf{1}$, apart from the replacement of the methylene groups $\mathrm{H}_{2}-12$ and $\mathrm{H}_{2}-13$ in 1 by two olefinic protons resonating at $\delta_{\mathrm{H}} 5.45$ and 5.48, respectively (Table 2). The aforementioned spectroscopic differences suggested that 2 features the same molecular framework as $\mathbf{1}$, bearing an additional double bond (C-12/13), which is in agreement with the 2 amu molecular weight difference observed between both compounds. This assumption was supported by the HMBC correlations from $\mathrm{H}_{2}-10$ and $\mathrm{H}_{2}-14$ to $\mathrm{C}-12\left(\delta_{\mathrm{c}} 129.8\right)$ and from $\mathrm{H}_{2}-11$ to C-13 $\left(\delta_{\mathrm{c}} 132.3\right)$, as well as by the COSY cross-peaks between $\mathrm{H}_{2}-11\left(\delta_{\mathrm{H}} 2.16\right)$ and $\mathrm{H}-12$, and between $\mathrm{H}_{2}-14\left(\delta_{\mathrm{H}} 2.00\right)$ and $\mathrm{H}-13$ (Figure 2). In analogy to 1, the structure of 2 was further corroborated by the EIMS fragment ion peaks at $m / z 175$ and 131, presumably originating from cleavage at C-5/6, as well as at $m / z 209$ and 97, from cleavage at C-11/12 (Figure S2-5). In addition, the geometry of the double bond C-12/13 was established as $E$ based on the large coupling constant between $\mathrm{H}-12$ and $\mathrm{H}-13\left({ }^{3} \mathrm{~J}=15.3 \mathrm{~Hz}\right)$. Accordingly, compound 2 was identified as a new natural product and the name cinachylenic acid $\mathrm{C}$ is proposed.

Table 2. ${ }^{1} \mathrm{H}(600 \mathrm{MHz}),{ }^{13} \mathrm{C}(150 \mathrm{MHz}), \mathrm{COSY}$, and HMBC data of cinachylenic acid C (2) in MeOH- $d_{4}$, $\delta$ in ppm.

\begin{tabular}{ccccc}
\hline Position & ${ }^{13} \mathbf{C}$, Type $^{\mathbf{1}}$ & ${ }^{\mathbf{1}} \mathbf{H}, \mathbf{m}(\boldsymbol{J}$ in Hz) & COSY & HMBC \\
\hline 1 & $-{ }^{2}$ & $-{ }^{3}$ & -3 & -3 \\
2 & $80.9, \mathrm{CH}$ & $3.76, \mathrm{dd}(7.6,4.6)$ & $3-\mathrm{H}$ & $\mathrm{C}-4 / 5 / 19$ \\
3 & $32.8, \mathrm{CH}_{2}$ & $1.74, \mathrm{~m} ; 1.68, \mathrm{~m}$ & $2 / 4-\mathrm{H}$ & -3 \\
4 & $25.3, \mathrm{CH}_{2}$ & $1.50, \mathrm{~m}$ & $3 / 5-\mathrm{H}$ & $\mathrm{C}-2 / 5 / 6$ \\
5 & $33.1, \mathrm{CH}_{2}$ & $2.10, \mathrm{br} \mathrm{qt}(7.3,2.0)$ & $4 / 6-\mathrm{H}$ & $\mathrm{C}-3 / 4 / 6 / 7$ \\
6 & $142.8, \mathrm{CH}$ & $5.95, \mathrm{dt}(15.7,7.3)$ & $5 / 7-\mathrm{H}$ & $\mathrm{C}-8$ \\
7 & $111.4, \mathrm{CH}$ & $5.46, \mathrm{~d}(15.7)$ & $6-\mathrm{H}$ & -3 \\
8 & $80.0, \mathrm{C}$ & -3 & -3 & -3 \\
9 & $88.6, \mathrm{C}$ & -3 & -3 & -3 \\
10 & $20.6, \mathrm{CH}_{2}$ & $2.28, \mathrm{td}(7.1,2.1)$ & $11-\mathrm{H}$ & $\mathrm{C}-8 / 9 / 11 / 12$ \\
11 & $32.7, \mathrm{CH}_{2}$ & $2.16, \mathrm{br} \mathrm{q}(6.5)$ & $10 / 12-\mathrm{H}$ & $\mathrm{C}-9 / 12 / 13$ \\
12 & $129.8, \mathrm{CH}^{2}$ & $5.45 \mathrm{dt}(15.3,6.5)$ & $11 / 13-\mathrm{H}$ & -3 \\
13 & $132.3, \mathrm{CH}^{2}$ & $5.48 \mathrm{dt}(15.3,6.0)$ & $12 / 14-\mathrm{H}$ & -3 \\
14 & $32.5, \mathrm{CH}_{2}$ & $2.00, \mathrm{br} \mathrm{q}(6.0)$ & $13 / 15-\mathrm{H}$ & $\mathrm{C}-12 / 13 / 16$ \\
15 & $30.4, \mathrm{CH}_{2}$ & $1.36, \mathrm{~m}$ & $14 / 16-\mathrm{H}$ & -3 \\
16 & $31.9, \mathrm{CH}_{2}$ & $1.30, \mathrm{~m}$ & $15 / 17-\mathrm{H}$ & $\mathrm{C}-15$ \\
17 & $23.3, \mathrm{CH}_{2}$ & $1.33, \mathrm{~m}$ & $16 / 18-\mathrm{H}$ & $\mathrm{C}-16$ \\
18 & $14.0, \mathrm{CH}_{3}$ & $0.90, \mathrm{t}(6.9)$ & $17-\mathrm{H}$ & $\mathrm{C}-16 / 17$ \\
19 & $58.0, \mathrm{CH}_{3}$ & $3.36, \mathrm{~s}$ & -3 & $\mathrm{C}-2$ \\
\hline
\end{tabular}

\subsection{Cinachylenic Acid D (3)}

Compound 3 was isolated as yellow oil and shared the same molecular formula with $2\left(\mathrm{C}_{19} \mathrm{H}_{30} \mathrm{O}_{3}\right)$, as indicated by the pseudomolecular ion peak at $m / z 307.2264[\mathrm{M}+\mathrm{H}]^{+}$in the HRESIMS. In a similar manner to 2 , the ${ }^{1} \mathrm{H}$ NMR data of $\mathbf{3}$ showed close similarity to those of $\mathbf{1}$ apart from the presence of an additional $E$-configured double-bond at C-15/16, as supported by the HMBC correlation from $\mathrm{H}_{3}-18$ to $\mathrm{C}-16\left(\delta_{\mathrm{C}} 132.9\right)$ and by the large coupling constant between $\mathrm{H}-15$ and $\mathrm{H}-16\left({ }^{3} \mathrm{~J}=15.3 \mathrm{~Hz}\right)$ (Table 3). Similarly, the structure of 3 was further corroborated by the EIMS fragment ion peaks at $\mathrm{m} / \mathrm{z}$ 149,175 and 278, presumably originating from cleavage at C-7/8, C-5/6 and C-16/17, respectively (Figure S3-5). Thus, 3 was characterized as the double-bond positional isomer of $\mathbf{2}$ and was named cinachylenic acid D. 
Table 3. ${ }^{1} \mathrm{H}(600 \mathrm{MHz}),{ }^{13} \mathrm{C}(150 \mathrm{MHz}), \mathrm{COSY}$, and HMBC data of cinachylenic acid D (3) in MeOH- $d_{4}$, $\delta$ in ppm.

\begin{tabular}{ccccc}
\hline Position & ${ }^{13} \mathbf{C}$, Type $^{\mathbf{1}}$ & ${ }^{\mathbf{1}} \mathbf{H}, \mathbf{m}(\boldsymbol{J}$ in Hz) & COSY & HMBC \\
\hline 1 & $-{ }^{2}$ & -4 & -4 & -4 \\
2 & $81.2, \mathrm{CH}$ & $3.74, \mathrm{dd}(8.1,4.7)$ & $3-\mathrm{H}$ & \\
3 & $32.6, \mathrm{CH}_{2}$ & $1.74, \mathrm{~m} ; 1.67, \mathrm{~m}$ & $2 / 4-\mathrm{H}$ & $\mathrm{C}-2 / 4 / 5$ \\
4 & $25.4, \mathrm{CH}_{2}$ & $1.50^{3}$ & $3 / 5-\mathrm{H}$ & $\mathrm{C}-2 / 5 / 6$ \\
5 & $33.2, \mathrm{CH}_{2}$ & $2.10, \mathrm{br} \mathrm{qt}(7.2,1.9)$ & $4 / 6-\mathrm{H}$ & $\mathrm{C}-3 / 4 / 6 / 7$ \\
6 & $142.8, \mathrm{CH}$ & $5.95, \mathrm{dt}(15.9,7.1)$ & $5 / 7-\mathrm{H}$ & $\mathrm{C}-5 / 8$ \\
7 & $111.4, \mathrm{CH}$ & $5.46, \mathrm{~d}(15.9)$ & $6-\mathrm{H}$ & -4 \\
8 & $79.8, \mathrm{C}$ & -4 & -4 & -4 \\
9 & $88.9, \mathrm{C}$ & -4 & -4 & -4 \\
10 & $19.5, \mathrm{CH}_{2}$ & $2.25, \mathrm{td}(7.0,2.2)$ & $11-\mathrm{H}$ & $\mathrm{C}-8 / 9 / 11 / 12$ \\
11 & $29.8, \mathrm{CH}_{2}$ & $1.49^{3}$ & $10 / 12-\mathrm{H}$ & $\mathrm{C}-9 / 10$ \\
12 & $29.1, \mathrm{CH}_{2}$ & $1.30, \mathrm{~m}$ & $11 / 13-\mathrm{H}$ & -4 \\
13 & $29.9, \mathrm{CH}_{2}$ & $1.38, \mathrm{~m}$ & $12 / 14-\mathrm{H}$ & $\mathrm{C}-14$ \\
14 & $30.3, \mathrm{CH}_{2}$ & $1.99^{3}$ & $13 / 15-\mathrm{H}$ & $\mathrm{C}-12 / 13$ \\
15 & -2 & $5.43^{3}$ & $14 / 16-\mathrm{H}$ & -4 \\
16 & $132.9, \mathrm{CH}^{3}$ & $5.39, \mathrm{dt}(15.3,6.3)$ & $15 / 17-\mathrm{H}$ & -4 \\
17 & $26.3, \mathrm{CH}_{2}$ & $1.99^{3}$ & $16 / 18-\mathrm{H}$ & $\mathrm{C}-18$ \\
18 & $14.2, \mathrm{CH}_{3}$ & $0.96, \mathrm{t}(7.5)$ & $17-\mathrm{H}$ & $\mathrm{C}-16 / 17$ \\
19 & $58.0, \mathrm{CH}_{3}$ & $3.36, \mathrm{~s}$ & -4 & $\mathrm{C}-2$ \\
\hline
\end{tabular}

${ }^{1}$ Data extracted from HMBC spectra, ${ }^{2}$ Not observed, ${ }^{3}$ Overlapped signals, ${ }^{4}$ None.

\subsection{Cinachylenic Acid A (4)}

Compound 4 was identified as 2-methoxy-trien-8-yne-octadecanoic acid, originally reported from the marine sponge $C$. australiensis, based on its NMR and HRESIMS data and by comparison with the literature [4]. The trivial name cinachylenic acid A is proposed.

\subsection{Absolute Configuration of Cinachylenic Acids A-D (1-4)}

The experimental ECD spectra of 1-3 were rather weak, suggesting that these compounds were obtained as enantiomeric mixtures. Nevertheless, their ECD spectra showed a positive Cotton effect at around $210 \mathrm{~nm}$ (Figures S1-6, S2-6, and S3-6), which could be attributed to the low enantiomeric excess of the $(S)$ enantiomer, as previously established for 2-methoxy acetylenes and fatty acids [9]. It should be noted that the ECD spectrum of 4 was not obtained due to its rapid decomposition during storage. However, the stereocenter C-2 in 4 was assumed to be $(S)$ based on its specific rotation value, which has a negative sign, similarly to those of $1-3$, as well as its close biogenetic relationship with the latter metabolites.

\subsection{Cinachyrazole A (5)}

Compound 5 was isolated as a white, amorphous solid. Its molecular formula was established as $\mathrm{C}_{7} \mathrm{H}_{10} \mathrm{~N}_{2} \mathrm{O}$ based on the pseudomolecular ion peak observed at $m / z 139.0865[\mathrm{M}+\mathrm{H}]^{+}$in the HRESIMS spectrum, corresponding to four degrees of unsaturation. Inspection of the ${ }^{1} \mathrm{H} N M R$ spectrum indicated the presence of three methyl groups at $\delta_{\mathrm{H}} 3.74\left(\mathrm{H}_{3}-7\right), 2.38\left(\mathrm{H}_{3}-8\right)$, and $2.51\left(\mathrm{H}_{3}-9\right)$, in addition to a singlet proton at $\delta_{\mathrm{H}} 9.85(\mathrm{H}-6)$ characteristic of an aldehyde group. Analysis of the $\mathrm{HMBC}$ spectrum confirmed the corresponding carbon signals and revealed in addition three $\mathrm{sp}^{2}$ quaternary carbon atoms at $\delta_{C} 151.7$ (C-3), 119.0 (C-4), and 147.1 (C-5) (Table 4). HMBC correlations from $\mathrm{H}_{3}-8$ to $\mathrm{C}-3$ and $\mathrm{C}-4$, from $\mathrm{H}_{3}-9$ to $\mathrm{C}-5$ and $\mathrm{C}-4$, and from $\mathrm{H}_{3}-7$ to $\mathrm{C}-5$ were indicative of a 1,3,5-trimethylpyrazole ring. The remaining aldehyde group was attached to $\mathrm{C}-4$ based on the observed HMBC correlations from H-6 to C-5 and C-3 (Figure 3). This structural assignment was further supported by the ROESY cross-peaks between $\mathrm{H}_{3}-7$ and $\mathrm{H}_{3}-9$ as well as between $\mathrm{H}-6$ and both $\mathrm{H}_{3}-8$ and $\mathrm{H}_{3}-9$. Hence, compound 5 was identified as a new natural product and was named cinachyrazole A. 
Table 4. ${ }^{1} \mathrm{H}$ NMR (600 MHz) and ${ }^{13} \mathrm{C}$ NMR $(150 \mathrm{MHz})$ data of 5, 6, and 7 in $\mathrm{MeOH}-d_{4}, \delta$ in ppm.

\begin{tabular}{|c|c|c|c|c|c|c|}
\hline \multirow{2}{*}{ Position } & \multicolumn{2}{|c|}{5} & \multicolumn{2}{|c|}{6} & \multicolumn{2}{|c|}{7} \\
\hline & ${ }^{1} \mathrm{H}, \mathrm{m}$ & ${ }^{13} \mathrm{C}$, Type ${ }^{1}$ & ${ }^{1} \mathrm{H}, \mathrm{m}$ & ${ }^{13} \mathrm{C}$, Type ${ }^{1}$ & ${ }^{1} \mathrm{H}, \mathrm{m}$ & ${ }^{13} \mathrm{C}$, Type ${ }^{1}$ \\
\hline 3 & -3 & $151.7, \mathrm{C}$ & -3 & 151.2, C & -3 & $147.9, \mathrm{C}$ \\
\hline 4 & -3 & $119.0, \mathrm{C}$ & -3 & $110.5, \mathrm{C}$ & -3 & $113.1, \mathrm{C}$ \\
\hline 5 & -3 & $147.1, \mathrm{C}$ & -3 & $145.7, \mathrm{C}$ & -3 & $141.4, \mathrm{C}$ \\
\hline 6 & $9.85, \mathrm{~s}$ & $186.8, \mathrm{CH}$ & -3 & -2 & $7.95, \mathrm{~s}$ & $138.0, \mathrm{CH}$ \\
\hline 7 & $3.74, \mathrm{~s}$ & $35.7, \mathrm{CH}_{3}$ & $3.72, \mathrm{~s}$ & $35.8, \mathrm{CH}_{3}$ & $3.73, \mathrm{~s}$ & $35.5, \mathrm{CH}_{3}$ \\
\hline 8 & $2.38, \mathrm{~s}$ & $12.4, \mathrm{CH}_{3}$ & $2.35, \mathrm{~s}$ & -2 & $2.35, \mathrm{~s}$ & 13.0, $\mathrm{CH}_{3}$ \\
\hline 9 & $2.51, \mathrm{~s}$ & $9.7, \mathrm{CH}_{3}$ & $2.50, \mathrm{~s}$ & $11.5, \mathrm{CH}_{3}$ & $2.45, \mathrm{~s}$ & $9.9, \mathrm{CH}_{3}$ \\
\hline$N^{\prime}-\mathrm{CHO}$ & -3 & -3 & -3 & -3 & $8.69, \mathrm{~s}$ & $166.1, \mathrm{CH}$ \\
\hline$N^{\prime}-\mathrm{CH}_{3}$ & -3 & -3 & -3 & -3 & $3.29, \mathrm{~s}$ & 26.4, $\mathrm{CH}_{3}$ \\
\hline
\end{tabular}

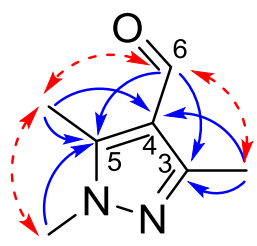

5

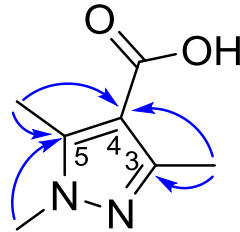

6

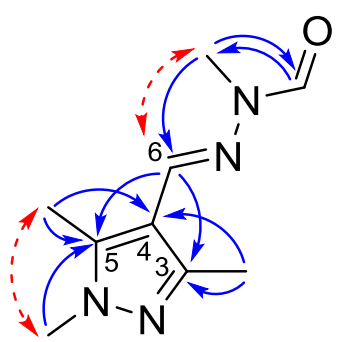

7

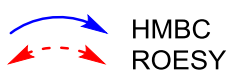

Figure 3. HMBC and ROESY correlations of 5-7.

\subsection{Cinachyrazole B (6)}

Compound 6 was isolated as a white, amorphous solid. Its molecular formula was determined as $\mathrm{C}_{7} \mathrm{H}_{10} \mathrm{~N}_{2} \mathrm{O}_{2}$, in accordance with the pseudomolecular ion peak observed at $\mathrm{m} / z 155.0814[\mathrm{M}+\mathrm{H}]^{+}$ in the HRESIMS spectrum. The ${ }^{1} \mathrm{H}$ NMR data of $\mathbf{6}$ were almost superimposable to those of 5 , except for the absence of the aldehyde group signal at $\delta_{\mathrm{H}} 9.85$ (H-6 in 5). This spectral difference suggested that 6 features the same pyrazole core structure as 5, apart from the replacement of the aldehyde group by a carboxylic acid group, which is in accordance with the 16 amu increase in the molecular weight compared to 5 (Table 4). This assumption was further corroborated by analysis of the HMBC spectrum of $\mathbf{6}$ (Figure 3). Accordingly, the structure of $\mathbf{6}$ was assigned and the compound was named cinachyrazole B.

\subsection{Cinachyrazole C (7)}

Compound 7 was isolated as a white, amorphous solid. The HRESIMS of 7 exhibited a pseudomolecular ion peak at $m / z 195.1241[\mathrm{M}+\mathrm{H}]^{+}$, consistent with the molecular formula $\mathrm{C}_{9} \mathrm{H}_{14} \mathrm{~N}_{4} \mathrm{O}$. The ${ }^{1} \mathrm{H}$ and ${ }^{13} \mathrm{C}$ NMR data of 7 denoted the same pyrazole basic unit as in $\mathbf{5}$ and $\mathbf{6}$ (Table 4). The remaining resonances included an olefinic signal at $\delta_{\mathrm{H}} 7.95\left(\mathrm{CH}-6, \delta_{\mathrm{c}} 138.0\right)$, an $N$-methyl group at $\delta_{\mathrm{H}} 3.29\left(\mathrm{~N}^{\prime}-\mathrm{CH}_{3}, \delta_{\mathrm{c}} 26.4\right)$, and an aldehyde group at $\delta_{\mathrm{H}} 8.69\left(N^{\prime}-\mathrm{CHO}, \delta_{\mathrm{c}} 166.1\right)$. These signals were indicative of the presence of an $N^{\prime}$-formyl- $N^{\prime}$-methyl-hydrazone moiety at $\mathrm{C}$-4, as supported by the HMBC correlations from $\mathrm{H}-6$ to $\mathrm{C}-5$ and $\mathrm{C}-3$ and from $\mathrm{H}_{3}-\mathrm{N}^{\prime}-\mathrm{CH}_{3}$ to $\mathrm{N}^{\prime}-\mathrm{CHO}$. In addition, the $E$ geometry of the double bond $(\mathrm{C}-6 / \mathrm{N})$ was established based on the observed ROESY cross-peak between $\mathrm{H}-6$ and $\mathrm{H}_{3}-\mathrm{N}^{\prime}-\mathrm{CH}_{3}$ (Figure 3). For compound 7, the name cinachyrazole $\mathrm{C}$ is suggested. 


\subsection{Proposed Biosynthetic Pathway for 5-7}

A plausible biosynthetic pathway for the isolated pyrazole derivatives 5-7 is proposed, which includes the linkage of an acetoacetic acid and an $\mathrm{N}$-acetyl- $\mathrm{N}$-methylhydrazine unit via a Schiff base formation followed by cyclization and dehydration reactions to form 6 . Subsequent reduction of the latter followed by a Schiff base formation with an $N$-formyl- $N$-methylhydrazine unit, a natural product originally isolated from the ascomycete fungus Gyromitra esculenta [10], would finally result in the formation of $\mathbf{5}$ and $\mathbf{7}$, respectively (Figure 4).

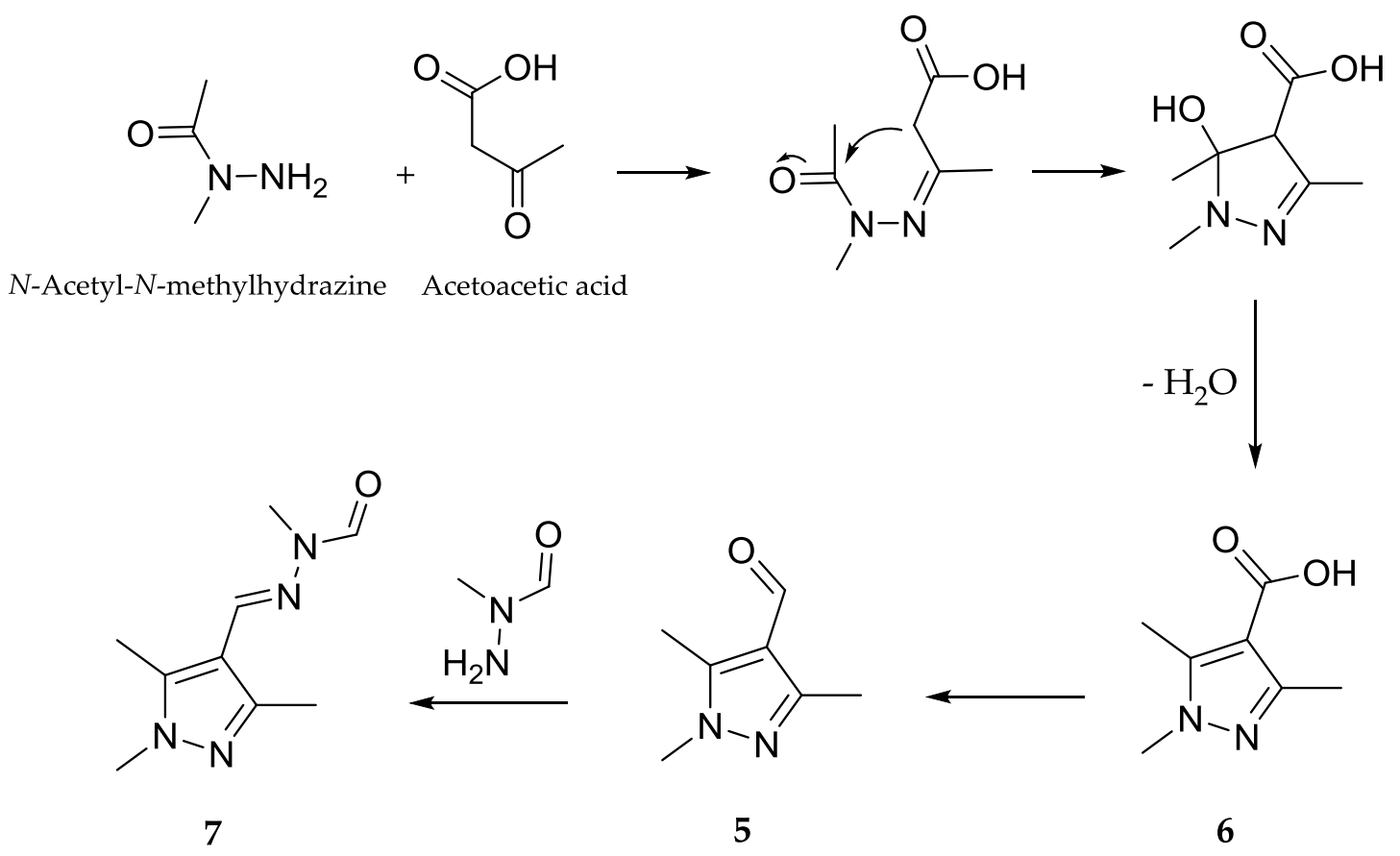

Figure 4. Proposed biosynthesis of 5-7.

\subsection{Bioactivity}

All isolated compounds (1-7) were evaluated for their effects on the growth of the L5178Y mouse lymphoma cell line employing the MTT assay. Interestingly, the acetylenic acid derivatives 1-4 exhibited pronounced cytotoxicity with an $\mathrm{IC}_{50}$ value of $0.3 \mu \mathrm{M}$ compared to the positive control kahalalide $\mathrm{F}\left(\mathrm{IC}_{50}=4.3 \mu \mathrm{M}\right)$. The pyrazole derivatives $(5-7)$ showed no cytotoxicity in the respective assay $\left(\mathrm{IC}_{50}>10 \mu \mathrm{M}\right)$.

\section{Discussion}

Compounds 1-4 are acetylenic acid derivatives possessing a methoxy group at C-2 as well as an acetylene group at C-8/9; however, they differ in the number and/or position of double bonds at their aliphatic chain (Figure 1). Other examples of 2-methoxy acetylenic acids from marine sponges include corticatic acids A-E, isolated from sponge Petrosia corticata with antifungal activity [11,12], taurospongin A from the sponge Hippospongia sp. with inhibitory activity against DNA polymerase $\beta$ and HIV reverse transcriptase [13], as well as halicynones A and B from the sponge Haliclona sp. with antitumor activity against the human colon tumor cell line (HCT-116) [14]. Compounds 5-7 possess an unusual 1,3,5-trimethylpyrazole core structure. It should be noted that 5 and $\mathbf{6}$ have been previously described as synthetic compounds and this is the first report of their isolation as natural products (Tables S5-8 and S6-6) [15,16]. Interestingly, compound 7 bears an additional hydrazone unit, which is rarely reported from marine invertebrates [11]. To the best of our knowledge, in addition to 7 , the only examples so far of sponge-derived compounds bearing a hydrazone unit include cinachyramine, 
likewise from a marine sponge of the genus Cinachyrella [12], as well as psammaplin G, a potent inhibitor of DNA methyltransferase, from the sponge Pseudoceratina purpurea [14].

\section{Materials and Methods}

\subsection{General Procedures}

1D and 2D NMR spectra were recorded on an AVANCE III HD 600 NMR spectrometer (Bruker, Karlsruhe, Germany) and the chemical shifts were referenced to the solvent residual peaks. HRESIMS and EIMS were measured on a UHR-QTOF maxi 4G (Bruker Daltonics, Bremen, Germany) or on a Thermo Finnigan TCQ 7000 mass spectrometer (Thermo Fisher Scientific GmbH, Bremen, Germany), respectively. UV data were recorded on a Perkin-Elmer Lambda $25 \mathrm{UV} /$ vis spectrometer (Perkin-Elmer, Waltham, MA, USA). ECD spectra were recorded with a J-810 spectropolarimeter (JASCO International Co. Ltd, Tokyo, Japan). The HPLC analysis was carried out using a Dionex UltiMate-3400SD equipped with a LPG-3400SD pump and a DAD 300RS photodiode array detector (Dionex Softron GmbH, Munich, Germany). The analytical column was filled with Eurosphere-10 C18 $(125 \times 4 \mathrm{~mm}, \mathrm{~L} \times$ i.d. $)$ (Knauer, Berlin, Germany), and the gradient consisted of $0 \mathrm{~min}(10 \% \mathrm{MeOH}) ; 5 \min (10 \% \mathrm{MeOH})$; $35 \mathrm{~min}(100 \% \mathrm{MeOH}) ; 45 \mathrm{~min}(100 \% \mathrm{MeOH})$, with $\mathrm{MeOH}, 0.1 \%$ formic acid in $\mathrm{H}_{2} \mathrm{O}$ solvent system. UV detection during HPLC was set at 235, 254, 280, and $340 \mathrm{~nm}$. A Merck Hitachi HPLC System (UV detector L-7400; pump L-7100; Eurosphere-100 C18, $300 \mathrm{~mm} \times 8 \mathrm{~mm}$, Knauer, Berlin, Germany), was used for semipreparative HPLC with a gradient system of $\mathrm{MeOH} / \mathrm{H}_{2} \mathrm{O}$ as mobile phase. Column chromatography was performed using Sephadex LH-20 (GE Healthcare Europe GmbH, Freiburg, Germany) and silica gel $60 \mathrm{M}(0.04-0.063 \mathrm{~mm})$ (Macherey-Nagel, Düren, Germany) as stationary phases. Thin-layer chromatography (TLC) was run using pre-coated silica gel 60 F254 plates (Merck KGaA, Darmstadt, Germany) followed by UV detection at $254 \mathrm{~nm}$ or after spraying the plates with anisaldehyde reagent. Optical rotations were measured using a Jasco P-2000 polarimeter (JASCO International Co., Ltd., Tokyo, Japan).

\subsection{Sponge Material}

The sponge specimen was collected by scuba at Ambon, Indonesia and was identified as Cinachyrella sp. by Dr. Nicole de Voogd (Naturalis Biodiversity Center, Leiden, The Netherlands). A voucher specimen was deposited at the Naturalis Biodiversity Center under the reference number RMNH POR. 10903. The sponge specimen was preserved in a mixture of EtOH and $\mathrm{H}_{2} \mathrm{O}$ (70:30) and stored in a freezer $\left(-20^{\circ} \mathrm{C}\right)$ prior to extraction.

\subsection{Extraction and Isolation}

The sponge (wet weight $400 \mathrm{~g}$ ) was cut into small pieces. The material was exhaustively extracted with methanol $(3 \times 1 \mathrm{~L})$ at room temperature and concentrated under vacuum to yield $1.4 \mathrm{~g}$ dry crude extract. The obtained extract was submitted to liquid-liquid partitioning to afford $n$-hexane, ethyl acetate and $n$-butanol fractions. The resulting fractions were further purified by column chromatography on Sephadex LH-20 (MeOH as mobile phase) and/or by vacuum liquid chromatography (VLC) using $n$-hexane/ethyl acetate and DCM/MeOH step gradient elution, followed by semipreparative HPLC, in a gradient system of $\mathrm{H}_{2} \mathrm{O} / \mathrm{MeOH}$, to yield $\mathbf{1}(1 \mathrm{mg}), \mathbf{2}(1.3 \mathrm{mg}), \mathbf{3}(0.8 \mathrm{mg})$, and $4(1 \mathrm{mg})$ from $n$-hexan, as well as $5(2.5 \mathrm{mg}), \mathbf{6}(2.0 \mathrm{mg})$, and $\mathbf{7}(1.0 \mathrm{mg})$ from ethyl acetate fraction.

Cinachylenic acid B (1): Yellow oil; $[\alpha]_{\mathrm{D}}^{20}=-11(c 0.1, \mathrm{MeOH}) ; \mathrm{UV}\left(\lambda_{\max }, \mathrm{MeOH}\right)(\log \varepsilon) 229(4.1)$; HRESIMS $m / z 309.2420[\mathrm{M}+\mathrm{H}]^{+}$(calcd. for $\mathrm{C}_{19} \mathrm{H}_{33} \mathrm{O}_{3}, 309.2424$ ); EIMS $m / z$ (relative intensity \%) 263 (32), 178 (26); ${ }^{1} \mathrm{H}$ and ${ }^{13} \mathrm{C}$ NMR spectroscopic data, see Table 1.

Cinachylenic acid C (2): Yellow oil; $[\alpha]_{\mathrm{D}}^{20}=-30\left(c\right.$ 0.1, MeOH); UV $\left(\lambda_{\max }, \mathrm{MeOH}\right)(\log \varepsilon) 228$ (4.0); HRESIMS $m / z 307.2266[\mathrm{M}+\mathrm{H}]^{+}$(calcd. for $\mathrm{C}_{19} \mathrm{H}_{31} \mathrm{O}_{3}, 307.2268$ ); EIMS $m / z$ (relative intensity \%) 209 (4), 175 (100), 131 (70), 97 (28); ${ }^{1} \mathrm{H}$ and ${ }^{13} \mathrm{C}$ NMR spectroscopic data, see Table 2. 
Cinachylenic acid D (3): Yellow oil; $[\alpha]_{\mathrm{D}}^{20}=-20(c 0.1, \mathrm{MeOH}) ; \mathrm{UV}\left(\lambda_{\max }, \mathrm{MeOH}\right)(\log \varepsilon) 228$ (3.9); HRESIMS $m / z 307.2264[\mathrm{M}+\mathrm{H}]^{+}$(calcd. for $\mathrm{C}_{19} \mathrm{H}_{31} \mathrm{O}_{3}, 307.2268$ ); EIMS $m / z$ (relative intensity \%) 278 (15), 175 (12), 149 (78), 131 (17); ${ }^{1} \mathrm{H}$ and ${ }^{13} \mathrm{C}$ NMR spectroscopic data, see Table 3.

Cinachyrazole A (5): White, amorphous solid; UV ( $\left.\lambda_{\max }, \mathrm{MeOH}\right)(\log \varepsilon) 201$ (3.3), 256 (3.8); HRESIMS $m / z$ 139.0865 [M + H] $]^{+}$(calcd. for $\mathrm{C}_{7} \mathrm{H}_{11} \mathrm{~N}_{2} \mathrm{O}, 139.0866$ ); ${ }^{1} \mathrm{H}$ and ${ }^{13} \mathrm{C}$ NMR spectroscopic data, see Table 4 .

Cinachyrazole B (6): White, amorphous solid; UV ( $\left.\lambda_{\max }, \mathrm{MeOH}\right)(\log \varepsilon) 229$ (3.5); HRESIMS $m / z$ 155.0814 [M+ H] ${ }^{+}$(calcd. for $\mathrm{C}_{7} \mathrm{H}_{11} \mathrm{~N}_{2} \mathrm{O}_{2}$ 155.0815); ${ }^{1} \mathrm{H}$ and ${ }^{13} \mathrm{C}$ NMR spectroscopic data, see Table 4 .

Cinachyrazole C (7): White, amorphous solid; UV $\left(\lambda_{\max }, \mathrm{MeOH}\right)(\log \varepsilon) 266$ (3.8), 288 (4.1); HRESIMS $m / z 195.1241[\mathrm{M}+\mathrm{H}]^{+}$(calcd. for $\mathrm{C}_{9} \mathrm{H}_{15} \mathrm{~N}_{4} \mathrm{O}, 195.1240$ ); ${ }^{1} \mathrm{H}$ and ${ }^{13} \mathrm{C}$ NMR spectroscopic data, see Table 4 .

\section{Conclusions}

In summary, a chemical investigation of the marine sponge Cinachyrella sp. collected in Indonesia afforded three new acetylenic acid derivatives (1-3) and one known congener (4), in addition to three new pyrazole alkaloids (5-7). The unusual pyrazole ring of the latter is postulated to be derived via a Schiff base formation between an acetoacetic acid and an $N$-acetyl- $N$-methylhydrazine unit. Notably, the acetylenic acid derivatives 1-4 showed strong inhibitory effect on the growth of L5178Y mouse lymphoma cell line with an $\mathrm{IC}_{50}$ value of $0.3 \mu \mathrm{M}$. In this context, our report highlights the metabolic potential of marine sponges of the genus Cinachyrella as a rich source of novel bioactive secondary metabolites.

Supplementary Materials: The following are available online at http:/ / www.mdpi.com/1660-3397/15/11/356/ s1, Supplementary Materials including HPLC, UV, HRESIMS, EIMS, 1D and 2D NMR spectra of 1-7.

Acknowledgments: Financial support from BMBF (project BALIPEND) granted to Peter Proksch and from Ministry of Science and Technology (MOST) to Wenhan Lin is gratefully acknowledged. Amin Mokhlesi gratefully acknowledges the Ministry of Science, Research and Technology (MSRT) of Iran for awarding him a scholarship. The authors acknowledge access to the Jülich-Düsseldorf Biomolecular NMR Center. Tibor Kurtán thanks the National Research, Development and Innovation Office (NKFI K120181) for financial support. The authors are indebted to Nicole de Voogd (Leiden, Naturalis Biodiversity Center, Leiden, The Netherlands) for identification of the sponge and acknowledge the support and help of Dr. Elizabeth Ferdinandus (University of Ambon, Indonesia) during sponge collection.

Author Contributions: Georgios Daletos and Peter Proksch designed the experiments and analyzed the data; Amin Mokhlesi isolated compounds 1-7 and wrote the paper with contributions and edits from all authors; Rudolf Hartmann performed and analyzed NMR measurements; Tibor Kurtán performed and analyzed CD measurements; Horst Weber assisted with the proposed biosynthesis of pyrazole derivatives (5-7); Wenhan Lin assisted with structure elucidation; Chaidir Chaidir assisted with sponge collection; Werner E. G. Müller performed cytotoxicity assays.

Conflicts of Interest: The authors declare no conflict of interest.

\section{References}

1. Mehbub, M.F.; Lei, J.; Franco, C.; Zhang, W. Marine sponge derived natural products between 2001 and 2010: Trends and opportunities for discovery of bioactives. Mar. Drugs 2014, 12, 4539-4577. [CrossRef] [PubMed]

2. Simmons, T.L.; Andrianasolo, E.; McPhail, K.; Flatt, P.; Gerwick, W.H. Marine natural products as anticancer drugs. Mol. Cancer Ther. 2005, 4, 333-342. [PubMed]

3. Barnathan, G.; Miralles, J.; Njinkoue, J.-M.; Mangoni, A.; Fattorusso, E.; Debitus, C.; Boury-Esnault, N.; Kornprobst, J.M. Sterol composition of three marine sponge species from the genus Cinachyrella. Comp. Biochem. Physiol. Part B: Comp. Biochem. 1992, 103, 1043-1047. [CrossRef]

4. Li, L.Y.; Deng, Z.W.; Li, J.; Fu, H.Z.; Lin, W.H. Chemical constituents from chinese marine sponge Cinachyrella australiensis. Beijing Da Хиe Xиe Bao 2004, 36, 7-12.

5. Barnathan, G.; Miralles, J.; Kornprobst, J.M. Sponge fatty acids-4. Co-occurrence of two isoprenoid fatty acids (4,8,12-trimethyltridecanoic and 5,9,13-trimethyltetradecanoic) in phospholipids of marine sponges from the genus Cinachrella. Nat. Prod. Lett. 1993, 3, 113-118. [CrossRef] 
6. Barnathan, G.; Doumenq, P.; Njinkoué, J.M.; Mirallès, J.; Debitus, C.; Lévi, C.; Komprobst, J.M. Sponge fatty acids. 3. Occurrence of series of n-7 monoenoic andiso-5,9 dienoic long-chain fatty acids in the phospholipids of the marine sponge Cinachyrella aff. schulzei keller. Lipids 1994, 29, 297. [CrossRef]

7. Wahidullah, S.; Naik, B.G.; Al-Fadhli, A.A. Chemotaxonomic study of the demosponge Cinachyrella cavernosa (lamarck). Biochem. Syst. Ecol. 2015, 58, 91-96. [CrossRef]

8. Oku, N.; Takada, K.; Fuller, R.W.; Wilson, J.A.; Peach, M.L.; Pannell, L.K.; McMahon, J.B.; Gustafson, K.R. Isolation, structural elucidation, and absolute stereochemistry of Enigmazole A, a cytotoxic phosphomacrolide from the papua new guinea marine sponge Cinachyrella enigmatica. J. Am. Chem. Soc. 2010, 132, 10278-10285. [CrossRef] [PubMed]

9. Zhao, Q.; Lee, S.Y.; Hong, J.; Lee, C.-O.; Im, K.S.; Sim, C.J.; Lee, D.S.; Jung, J.H. New acetylenic acids from the marine sponge Stelletta species. J. Nat. Prod. 2003, 66, 408-411. [CrossRef] [PubMed]

10. Patocka, J.; Pita, R.; Kuca, K. Gyromitrin, mushroom toxin of Gyromitra spp. Mil. Med. Sci. Lett. (Voj. Zdrav. Listy) 2012, 81, 61.

11. Le Goff, G.; Ouazzani, J. Natural hydrazine-containing compounds: Biosynthesis, isolation, biological activities and synthesis. Bioorganic Med. Chem. 2014, 22, 6529-6544. [CrossRef] [PubMed]

12. Shimogawa, H.; Kuribayashi, S.; Teruya, T.; Suenaga, K.; Kigoshi, H. Cinachyramine, the novel alkaloid possessing a hydrazone and two aminals from Cinachyrella sp. Tetrahedron Lett. 2006, 47, 1409-1411. [CrossRef]

13. Ishiyama, H.; Ishibashi, M.; Ogawa, A.; Yoshida, S.; Kobayashi, J. Taurospongin a, a novel acetylenic fatty acid derivative inhibiting DNA polymerase $\beta$ and HIV reverse transcriptase from sponge Hippospongia sp. J. Org. Chem. 1997, 62, 3831-3836. [CrossRef]

14. Piña, I.C.; Gautschi, J.T.; Wang, G.Y.S.; Sanders, M.L.; Schmitz, F.J.; France, D.; Cornell-Kennon, S.; Sambucetti, L.C.; Remiszewski, S.W.; Perez, L.B. Psammaplins from the sponge Pseudoceratina purpurea: Inhibition of both histone deacetylase and DNA methyltransferase. J. Org. Chem. 2003, 68, 3866-3873. [CrossRef] [PubMed]

15. Attaryan, O.S.; Antanosyan, S.K.; Panosyan, G.A.; Asratyan, G.V.; Matsoyan, S.G. Vilsmeier-Haak formylation of 3,5-dimethylpyrazoles. Rus. J. Gen. Chem. 2006, 76, 1817-1819. [CrossRef]

16. Chiriac, C.I. The direct carboxylation of pyrazoles. Synthesis 1986, 9, 753-755. [CrossRef] 